\title{
Formas provisorias de conjurar el pasado. Ruinas e intervenciones artísticas en la Villa San Luis de Las Condes ${ }^{1}$
}

\author{
Provisional forms of conjuring the past. \\ Ruins and artistic interventions in Villa San Luis of Las Condes \\ Dra. Carla Pinochet Cobos $^{\mathrm{a}}$ \& Lic. Constanza Tobar Tapia ${ }^{\mathrm{b}}$ \\ aDepartamento de Antropología, Universidad Alberto Hurtado, Chile \\ $\bowtie$ carlaasecas@gmail.com [orcid.org/0000-0002-8188-2572] \\ bUniversidad de Chile, Chile \\ constanza.tobar.t@gmail.com [orcid.org/0000-0001-7929-5873]
}

\begin{abstract}
RESUMEN
El artículo contribuye a la discusión en torno al concepto de ruina, tomando como caso de análisis los vestigios de la Villa San Luis, en la comuna de Las Condes (Santiago de Chile). En el marco del escenario de disputas patrimoniales e inmobiliarias que enfrenta este icónico proyecto habitacional impulsado por el gobierno socialista de Salvador Allende, observamos los modos en que la ruina representa un quiebre sensorial en la pretendida continuidad espacio/temporal de la ciudad, y analizamos un conjunto de estrategias artísticas en torno a este hito que -mediante recursos visuales sugerentes y abiertos- le devuelven visibilidad y memoria a un espacio amenazado por el avance implacable de la urbe.
\end{abstract}

PALABRAS CLAVE: ruinas urbanas, patrimonio, proyecto socialista, intervención artística, inminencia.

\section{ABSTRACT}

The article contributes to the discussion about the concept of ruin, taking as a case of analysis the vestiges of Villa San Luis, in the commune of Las Condes (Santiago of Chile). Under the current scenario of heritage and property disputes faced by this iconic housing project promoted by the socialist government of Salvador Allende, we observe the ways in which the ruin represents a sensory rupture in the supposed space/time continuity of the city,

1 Artículo realizado en el marco del proyecto FONDECYT Regular No 1180352, "Ruinas urbanas. Réplicas de memoria en ciudades latinoamericanas. Santiago, Quito y Bogotá”. Investigadora responsable: Francisca Márquez Belloni. Coinvestigadoras: Amalia Nuevo, Javiera Bustamante y Carla Pinochet. 
and we analyze a set of artistic strategies around this milestone that -through suggestive and open visual resources- return visibility and memory to a space threatened by the relentless advance of the city.

KEY WORDS: urban ruins, heritage, socialist project, artistic intervention, imminence.

\section{INTRODUCCIÓN}

Durante la última década, los vestigios urbanos del proyecto socialista del Presidente Salvador Allende en la ciudad de Santiago han experimentado transformaciones significativas. Dos breves imágenes ilustran estas conversiones: el año 2010, en el corazón del centro histórico, se reinaugura el Centro Cultural GAM sobre lo que alguna vez fue la UNCTAD, edificio que el gobierno de la Unidad Popular construyó para alojar la Tercera Conferencia Mundial de Comercio y Desarrollo de las Naciones Unidas en 1972, y que tras el golpe de Estado pasó a ser sede del Poder Ejecutivo y Legislativo del gobierno militar. Por otra parte, en 2016, tras cuarenta años de abandono, el llamado «Elefante Blanco» de la comuna de Pedro Aguirre Cerda -emblemático proyecto de un «Hospital del trabajador» cuyas obras fueron iniciadas por la administración socialista- se convierte finalmente en el Núcleo Ochagavía, centro privado destinado al bodegaje industrial. Aun en sus remodelaciones y nuevos usos, estos hitos arquitectónicos se nos presentan como testigos obstinados de un modo de imaginar la ciudad que fue violentamente interrumpido por la dictadura cívico-militar que le sucedió en el poder. Se trata de un proyecto urbano que, materializado mayoritariamente a través de la Corporación de Mejoramiento Urbano (CORMU), impulsó la construcción de nuevas edificaciones, la modificación de proyectos en curso y la remodelación de espacios², instalando un horizonte valórico en la planificación urbana marcado por la igualdad en el acceso y el derecho a la ciudad.

¿De qué forma la historia se inscribe en las edificaciones de la ciudad? ¿Qué queda de los proyectos urbanos que una sociedad deja atrás para construir nuevos relatos y nuevas instalaciones? ¿En qué medida subsisten, aún en sus residuos reacondicionados, las utopías sociales? En este artículo, queremos abordar el devenir histórico de este conjunto de iniciativas del proyecto socialista deteniéndonos en un capítulo particularmente disputado de su historia residual: la Villa Ministro Carlos Cortés, más conocida como Villa San Luis, emplazada en la comuna de Las Condes. A partir del trabajo desde la dimensión sensible que realiza un conjunto de intervenciones artísticas recientes, examinaremos sus particulares coordenadas sociopolíticas en tanto nodo en el que convergen diversos intereses en pugna.

Además de los hitos ya mencionados, destaca dentro de este programa la remodelación San Borja, el Parque O’Higgins (ex Parque Cousiño), un conjunto de balnearios populares y centros de turismo que se ubicaron a lo largo del país (Gámez, 2006; Lawner, 2013; Pavez, 2015); y otras iniciativas que sólo alcanzaron su etapa de diseño, como el “Área de remodelación en el centro de Santiago de Chile”, que estuvo sometido a concurso internacional en 1972 (Siebert, 2015). 
De esta forma, con los litigios judiciales y las declaratorias patrimoniales como telón de fondo, nuestro análisis busca elaborar una reflexión acerca de los modos en que la memoria subsiste en el espacio urbano, y el papel singular que desempeñan las ruinas al recordarnos, con su materialidad impertinente, otros relatos posibles que la historia ha ido empolvando.

\section{BREVE HISTORIA DE UN PROYECTO TRUNCADO}

Una de las piedras angulares del proyecto socialista de Salvador Allende en términos de planificación urbana fue su política habitacional, con la cual pretendía entregar una solución al problema de vivienda que aquejaba a una parte importante de la población denominada "los sin casa" (Raposo, 2001; Montealegre, 2010). La centralidad y urgencia de esta tarea, anunciada desde la propia campaña presidencial (Unidad Popular, 1970), respondía a la convicción de desarticular la histórica segregación social de la ciudad y favorecer la participación de los sectores populares en el diseño de la planificación urbana, particularmente de los espacios que habitarían en el futuro (Gross, 1991; Raposo \& Valencia, 2009; Montealegre, 2010). Entre estas iniciativas, mayormente concentradas en la región Metropolitana, destacan los seccionales Tupac Amaru, Mapocho-Bulnes, Padres Carmelitos, Pozos Areneros y San Luis de Las Condes (Raposo, Raposo \& Valencia, 2005; Pavez, 2015). Este último proyecto, conocido como Villa San Luis, se ha constituido como uno de los casos más paradigmáticos del programa urbano socialista, tanto por su magnitud simbólica como por las enrevesadas disputas patrimoniales a las que se ha visto sujeto en tiempos recientes.

Los inicios de la Villa San Luis se remontan a la expropiación y cesión de terrenos del ex fundo San Luis a la CORMU durante el gobierno de Eduardo Frei Montalva. El propósito inicial del gobierno era diseñar un proyecto urbano destinado a viviendas para clases medias y altas, el que también incluía un centro administrativo-comercial y un parque. Esta iniciativa, elaborada por el arquitecto Miguel Eyquem y bautizada "Remodelación Parque San Luis", no alcanzó a ponerse en marcha bajo el mandato del ex presidente Frei Montalva y fue heredada por el gobierno consecutivo. Es así como la idea original fue modificada en el gobierno de Allende para responder al problema habitacional de la época: el área de intervención del proyecto y su monumentalidad se redujeron para priorizar la construcción de viviendas destinadas a las clases populares (Consejo de Monumentos Nacionales, 2017; Allende \& Olave, 2018). En este proceso la CORMU y su director ejecutivo, el arquitecto Miguel Lawner, tuvieron un rol protagónico en el trazado del nuevo plan.

La primera fase de la Villa San Luis culminó en 1972 con la entrega de 300 departamentos a un grupo de pobladores, quienes decidieron rebautizar el conjunto habitacional como "Villa Compañero Ministro Carlos Cortés" (Sánchez, 2017). El Golpe de Estado de 1973 truncó de forma violenta el desarrollo del proyecto y así su segunda etapa nunca fue concretada. Los días posteriores al 11 de septiembre comenzaron allanamientos y detenciones en la Villa, siendo tan sólo las primeras intervenciones militares que ocurrirían en el lugar. El 
retorno a su nombre original -Villa San Luis- estuvo marcado por las amenazas latentes de desalojo que se concretaron finalmente entre 1976 y 1988, bajo el argumento de que se trataba de una toma de terreno pues sus habitantes no contaban con los títulos de propiedad de los departamentos ${ }^{3}$ (Lawner, 2007; Chiara \& Pulgar, 2008). En la medida que se les forzó a movilizarse a la periferia de la ciudad, suboficiales del Ejército comenzaron a habitar sus antiguos hogares, aunque nuevamente sin títulos de propiedad. Hacia el término de la dictadura sólo un centenar de las familias originales habitaban la Villa, sin conocimiento de por qué no las habían desalojado y con temor de que lo hicieran (Allende \& Olave, 2018).

Las acciones que tuvieron lugar en los gobiernos de la "Concertación de Partidos por la Democracia” -gobiernos marcados por la transición política- únicamente acentuarían las disputas actuales en torno a la Villa. En 1989, Augusto Pinochet dictó un decreto que transfería la propiedad de los terrenos a Bienes Nacionales, entidad que dos años más tarde, en el gobierno del Presidente Patricio Aylwin, traspasaría sus derechos al Ministerio de Defensa, Subsecretaría de Guerra y Comando de Bienestar del Ejército, señalando que debían emplearse de forma exclusiva para fines habitacionales (Lawner, 2007; Allende \& Olave, 2018). Ya que los terrenos no podían venderse en estas condiciones legales, el Ejército decide transferirlos a la categoría de «propiedad de afectación fiscal» para usufructuar económicamente de ellos. Por esta vía, ingresa un nuevo agente al conflicto: la Inmobiliaria Presidente Riesco S.A. que concreta la compra de la propiedad en 1997. Para ejecutar su proyecto inmobiliario, que contrasta radicalmente con el espíritu de la propuesta de la Unidad Popular, inicia una nueva ola de desalojos que esta vez también afecta a los suboficiales y que da paso a las primeras demoliciones (Chiara \& Pulgar, 2008; Consejo de Monumentos Nacionales, 2017; Sugranyes, 2017; Allende \& Olave, 2018).

En la década de 1990, los antiguos vecinos comenzaron a agruparse para hacer visible la situación a la que se vieron sometidos y exigir una restitución de lo que se les había despojado. Así se conforma el "Movimiento Reconquista de Nuestros Derechos” que canaliza las demandas judiciales de los ex pobladores en contra del Ejército y, más tarde, contra la inmobiliaria. Aunque logran ganar un caso en 2002, el saldo general no fue positivo: las trescientas familias demandantes recibieron menos de un millón de pesos cada una, pues los \$590.000.000 que recibieron de la inmobiliaria debieron destinarse a los costos de una demanda que se extendió por cinco largos años (Raposo et al. 2005; Lawner, 2007; Allende \& Olave, 2018). En paralelo los residentes que permanecían en la Villa pudieron dar un significativo paso en 1999, cuando recibieron de forma gratuita sus títulos de dominio

\footnotetext{
De acuerdo a Pablo Seguel, encargado de declaratorias vinculadas a Sitios de Memoria y Derechos Humanos del Consejo de Monumentos Nacionales, el sector uno del proyecto norte de la Villa San Luis no tuvo la recepción final de obras, de modo que la Corhabit no pudo tramitar los títulos de dominio de los destinatarios de esos espacios. Sin embargo, los pobladores pagaron los dividendos de sus casas en modalidad de descuento por planillas, por aproximadamente dos años: "En estricto rigor -señala Seguel- aquí se generaba un conflicto porque si bien existe un reconocimiento de un derecho en el sentido de que se asigna una casa, formalmente no son los propietarios porque no se ejecutó la recepción final de la obra”. (Entrevista realizada por Javiera Bustamante y Vicente Yáñez. Todas las citas a Pablo Seguel incluidas en este artículo corresponden a dicha entrevista).
} 
por parte de Bienes Nacionales (Consejo de Monumentos Nacionales, 2017). Sin embargo, este centenar de familias fue disminuyendo con el paso del tiempo, debido a las presiones ejercidas por la Municipalidad y la Inmobiliaria que llegó a ofrecerles sumas millonarias por sus propiedades. La resistencia a estos embates fue apagándose lentamente y en 2015 la última habitante de Villa San Luis abandonó su vivienda (Chiara \& Pulgar, 2008; Toro, 2014; Allende \& Olave, 2018).

Si bien hubo más procedimientos judiciales protagonizados por los ex pobladores, la Inmobiliaria y el Ejército, el dilema patrimonial tras este conflicto se hizo explícito recién en 2017. El realizador audiovisual Jaime Díaz y el ex director de la CORMU Miguel Lawner, en compañía de otras personas, conformaron el Comité de Defensa de la Villa San Luis y levantaron la solicitud ante el Consejo de Monumentos Nacionales para declararla Monumento Histórico Nacional (Sugranyes, 2017; Allende \& Olave, 2018). Así, a fines de julio del mismo año, se aprobó una declaratoria desde dicha institución para que Villa San Luis se considerara monumento, indicando los siguientes motivos: (1) es un vestigio material de un proceso de desalojo forzado colectivo en el contexto de la dictadura cívico-militar; (2) es la expresión de una política pública de integración social y participativa; (3) es el diseño de un arquitecto que obtuvo el Premio Nacional de Urbanismo, Miguel Eyquem. Entre ellos, el más relevante para el Consejo guarda relación con el primer punto, ya que la puesta en valor de este lugar fue considerada una reparación simbólica para las víctimas (Consejo de Monumentos Nacionales, 2017)4.

Las reacciones de la Inmobiliaria Presidente Riesco ante la declaratoria fueron inmediatas. La imposibilidad de concretar su proyecto significaría una pérdida económica sustantiva para la empresa dado que el valor del suelo donde se emplaza la Villa es uno de los más costosos del país. A raíz de este interés es que la inmobiliaria demolió parcialmente los edificios que se mantenían en pie mientras se realizaba el litigio legal que daría a conocer la declaratoria. Los vecinos de la zona y el Comité de Defensa de la Villa denunciaron el hecho a la prensa y a las autoridades por lo que la empresa se vio en la obligación de detenerse, aunque ya había cumplido parcialmente su cometido (Consejo de Monumentos Nacionales, 2017; Lawner, 2017). Meses más tarde, la inmobiliaria ofreció la construcción de un sitio de memoria entre las nuevas edificaciones para responder a la demanda del Comité de Defensa y de los ex pobladores, pero ellos rechazaron la propuesta (González, 2017; Lawner, 2017). En 2018 la Corte de Apelaciones rechazó el recurso que impuso la inmobiliaria contra el Ministerio de Educación que, hasta antes de la creación del Ministerio de las Culturas, se encargaba de las declaratorias de Monumentos Nacionales (Cerna, 2018). La demanda de la Inmobiliaria Presidente Riesco para recuperar la propiedad se mantiene en desarrollo, con el argumento de que su compra fue legítima, mientras que Villa San Luis sigue vigente como Monumento Histórico Nacional (Allende \& Olave, 2018).

Todas estas demandas públicas y gestiones judiciales han ido cambiando provisoria y sucesivamente el estatuto legal de los restos de la Villa: quién es su legítimo dueño, cuál

Entrevista a Pablo Seguel. 
es su valor patrimonial, quiénes tienen derecho a decidir sobre su destino. Sin embargo, en el centro neurálgico de la comuna de Las Condes, lo que permanece son -todavía- las ruinas. Con sus lozas en declive y un claro estado de abandono, esta edificación en pugna continúa contrastando de forma notable con el paisaje urbano que le rodea. Su materialidad en deterioro sigue siendo una evidencia persistente de que, antes de los rascacielos espejados y el paso apurado de los oficinistas hacia sus edificios corporativos, hubo en esta misma manzana un espacio de residencia popular y un proyecto de integración urbana. ¿En qué consiste, entonces, el poder sobrecogedor de las ruinas? ¿Cómo operan estos espacios heterotópicos que rompen con el flujo y la tesitura de la dinámica urbana? ${ }^{5}$. Antes de abordar la especificidad del concepto, resulta necesario hacer algunas distinciones que permiten observar la noción de ruina a la luz de otros conceptos aledaños, indagando en los modos en que estas configuraciones nos ayudan a comprender los procesos atravesados por la Villa San Luis en las últimas décadas.

\section{ESCOMBRO, RUINA Y PATRIMONIO}

“Los bombardeos no produjeron simplemente ruinas. Produjeron escombros”, señala Huyssen (2007). ¿Qué operación, entonces, hace posible el tránsito entre los escombros y las ruinas? En este punto, nos interesa reflexionar acerca de la relación entre la materialidad de los vestigios del pasado y el relato que se construye en torno a ésta, estableciendo una distinción entre tres momentos diferentes de su producción simbólica: el escombro, la ruina y el patrimonio. Para el autor, hay ruinas -y no sólo escombros- cuando tiene lugar una estetización que organiza de forma perceptible los remanentes abandonados del pasado. Hablamos de «escombros», de este modo, cuando no se percibe más que la materialidad destrozada de un hito arquitectónico cuya forma anterior ya no resulta inteligible. El ámbito del escombro, en este sentido, es el dominio del olvido: como sostiene el proyecto de investigación en el que se enmarca este texto, la posibilidad de resistencia de la ruina urbana a su borramiento se correlaciona con la capacidad de los actores sociales de reactualizar esa narrativa fundacional en sus formas materiales (Márquez et al. 2019). Para que exista «ruina», entonces, es preciso que exista un relato que le devuelva su valor simbólico. Las reflexiones de Beasley Murray en este sentido resultan esclarecedoras:

Una ruina es una estructura que tiene que completarse por otros medios: a través del discurso, de la narración, de los relatos. [...] Al estar incompletas, las ruinas no pueden hablar por sí mismas y tienen que ser explicadas; requieren un suplemento que les asegure su representabilidad. Necesitan algo más. De este modo es cómo las ruinas vienen a ser la imagen misma de la dependencia de lo material en lo inmaterial, de la

Para Foucault, las heterotopías son contra-emplazamientos capaces de romper con el tiempo tradicional y yuxtaponer en un solo lugar múltiples espacios en principio incompatibles (1999). 
promesa narrativa de compensar la pérdida por otros medios, de la subordinación de lo real al mundo (2015, s/p).

De esta manera, la ruina implica una materialidad deteriorada pero legible, cuya condición de posibilidad radica en un trabajo en torno a la memoria. En tierras latinoamericanas, como bien han señalado Lazzara y Unruh (2009), las ruinas urbanas entrañan la convergencia, por una parte, del desgaste físico del tiempo y los desastres naturales; y por la otra, de la incidencia brutal de la violencia humana y los abusos de poder. Lejos de ser el efecto de un plácido envejecimiento material, muchos de los sitios que observamos en esta región se encuentran marcados por la impronta de los desechos de cuerpos, experiencias e ilusiones colectivas truncadas; como en la propia Villa San Luis, se acumulan “tradiciones caducas que evocan la devastación de las utopías fallidas de los proyectos políticos” (Richard, 2009, p. 3). Así, el estado de ruina siempre nos retrotrae a un pasado latente, que admite lecturas múltiples y fragmentarias.

Podemos identificar, por otra parte, una nueva progresión en el vínculo entre materialidad y relato que se establece en torno a estos vestigios urbanos. Si la ruina se caracteriza por su estado de latencia y moviliza diversos -y a veces, contradictorios- procesos de construcción de sentido, su constitución como hito patrimonial implica la definición de un marco estable en torno a su valor y significado. El proceso de patrimonialización de una ruina puede leerse, entonces, como un esfuerzo por fijar y consolidar un sentido a partir de su materialidad aún dispersa, utilizando diferentes instrumentos para hacer valer esta lectura en el ámbito público. Debemos entender esta tentativa de clausura más como una voluntad que como una operación efectiva: tal y como ha quedado expresado en la vasta discusión en torno a los sitios de memoria, existen enormes dificultades para plasmar en el espacio un conjunto de memorias que -por definición- están en permanente disputa y transformación. Los monumentos, memoriales e inscripciones connotan un "afán definitivo" que suele entrar en conflicto con una historia que no admite verdades últimas (Schindel, 2009); de forma que no se trata de un mensaje unívoco y consensuado, sino un escenario de luchas de sentido (Jelin \& Langland, 2003). No obstante, aún en su carácter polémico, la noción de «patrimonio» implica un reconocimiento intersubjetivo y manifiesto de aquello que la ruina sólo puede sugerir, lo cual encuentra correlato en determinadas herramientas -jurídicas y sociales- para preservar estos sentidos ${ }^{6}$. Bajo esta clave de lectura, las luchas de

6 Al abordar la economía política del patrimonio, y definiendo dicho concepto como "la sombra acarreada del valor de uso, después del paso ciclónico del valor de cambio” (Déotte, 1998, p. 131), J. L. Déotte ha señalado que ni el proceso de conversión mercantil ni el proceso patrimonial requieren de pensamiento. Así, en tiempos contemporáneos, el patrimonio se habría emancipado y circularía de forma independiente a las lógicas y proyectos que alguna vez debieron justificarlo. Los museos, en la emergencia postmoderna, no responden a necesidades, sino que "proliferan, como metástasis, llenándose de colecciones diversas e inesperadas" (1998, p. 131). Aunque este texto constituye un antecedente significativo de la reflexión que aquí hacemos, nos parece que la lectura de Déotte sobreestima -quizás por el momento en el que escribe, o las coordenadas geopolíticas (europeas) desde las que lo hace- el sinsentido postmodernista: aun cuando el patrimonio ya no busca consolidar grandes proyectos como "instituir la unidad nacional" o "iluminar el pueblo" (1998, p. 131), pensamos que existe en los procesos de patrimonialización una vocación de clausura o de relato hegemónico detrás del cual sí reside el "pensamiento". A nuestro juicio, la ruina puede constituir un momento previo a ese anudamiento, que devela la potencia divergente de sus formas materiales. 
las agrupaciones ciudadanas por la defensa de la Villa San Luis -recientemente constituidas como fundación- constituyen esfuerzos por instalar en la escena pública el valor histórico de esas ruinas en tanto vestigio de un proyecto político interrumpido y evidencia de un despojo violento e ilegítimo por parte del Estado a los pobladores. Si el reconocimiento patrimonial de estos elementos, a través de la declaratoria de Monumento Histórico Nacional, atenta directamente contra los intereses de otros actores -como las inmobiliarias involucradas y los agentes municipales-, es porque clausura las posibilidades en torno a la Villa: aún en su carácter abierto y controvertido, el patrimonio establece un estricto margen de acción en torno a estos edificios que limita lo que se puede hacer con ellos.

La declaratoria patrimonial de la Villa San Luis abre un escenario de posibilidades diversas que ponen en el centro el problema de la gestión de este sitio. En enero de 2018, el Consejo de Monumentos Nacionales aprobó una intervención de memoria en el sitio, lo que implica que los residuos materiales de la Villa pueden ser removidos para la construcción de un memorial, que eventualmente podría utilizar las piezas de la ruina. Como apunta P. Seguel, los valores que deberán regir este hito guardan relación con las vulneraciones de derecho que se vivieron en la etapa uno de la Villa San Luis; es decir, se deberá poner de relieve la dimensión reparatoria hacia las víctimas y visibilizar la importancia del proyecto histórico asociado al sitio.

“Ahí se abre un arco de intervenciones. Todas son posibles y probables. Se puede conservar en su estado ruinoso; se puede reparar el inmueble; se puede reconstruir el inmueble; se puede sacar todo y hacer otra cosa. El tema es que, como la gestión patrimonial, la conservación y la intervención son un área cualitativa con componentes técnicos, lo que se aplica en ese espacio son modelos de gestión para destrabar estos conflictos”.

De este modo, incluso cuando la constitución del sitio como patrimonio significa una estabilización de sus sentidos y el resguardo de una lectura en torno a éste, la diversidad de actores e intereses involucrados nos enfrenta a una arena de conflictos. Se habla, por un lado, de la posibilidad de realizar un concurso público en el que participen como jurado los distintos agentes involucrados en el caso: la Fundación Villa San Luis, los propietarios, el Consejo de Monumentos Nacionales, tal vez la Municipalidad de Las Condes. Por otra parte, podría abordarse como una política de Estado, aplicando consecuentemente los lineamientos de la Ley SERVIU (expropiación), y asumiendo el Estado las labores de reconstrucción del sitio o la creación de un museo de sitio. Un tercer escenario estaría marcado por la acción privada: la inmobiliaria que posee el terreno puede optar por no hacer nada en el sitio. O eventualmente, como una cuarta posibilidad, dicho agente privado puede rechazar las negociaciones con el Consejo y los solicitantes, ingresando un proyecto a través del Servicio de Evaluación de Impacto Ambiental, en la medida en que se trata de un sitio de afectación patrimonial $^{7}$.

Entrevista a Pablo Seguel. 
En resumidas cuentas, «escombro», «ruina»y «patrimonio» pueden ser entendidos como tres momentos -o tal vez tres estados- por los que pueden atravesar los fragmentos en deterioro de un, otrora, bien cultural. Su orden subsecuente indica un anudamiento progresivo entre una materialidad y su relato, de modo que, mientras en el escombro esta capacidad simbólica de articulación es casi ilegible, en el estado de patrimonio predomina una lectura oficial que busca fijar los sentidos que dicha objetualidad convoca. Este artículo presta especial atención a la categoría intermedia: la condición de ruina. Sostenemos aquí que dicha noción permite abordar estas materialidades derruidas en un estado de indeterminación particularmente productivo, puesto que, si bien en sus huellas físicas es posible identificar diversos trazos de la historia y del pasado, su dispersión y deterioro operan como una resistencia a la clausura definitiva de un relato monolítico.

Nos detendremos, a continuación, en algunos aspectos conceptuales de la noción de ruina, analizando desde las especificidades de la Villa San Luis sus potencialidades para convocar la memoria y alterar la continuidad de la ciudad hegemónica. A partir de este análisis, será posible situar las intervenciones artísticas que han puesto atención en la Villa San Luis en los últimos años, dando cuenta del papel que desempeñan en los procesos contemporáneos de memoria y agencia política.

\section{LAS RUINAS COMO PUESTA EN CRISIS DE LA CIUDAD CONTEMPORÁNEA}

Diversos autores han apuntado al vínculo íntimo entre la ruina y la nostalgia. En su materialidad presente, la ruina admite la supervivencia desarticulada de ciertos trazos del pasado que parecen brillar desde otro tiempo. Se trata, en esta medida, de una convergencia de temporalidades y espacialidades otras que, aunque se encuentran latentes resultan, al mismo tiempo, inaccesibles y esquivas. Esa resistencia que ofrece el pasado inscrito en la ruina entraña una añoranza marcada por la imposibilidad: como señala A. Huyssen, las ruinas de la modernidad se encuentran atravesadas por la nostalgia de un futuro diferente (2007), es decir, por la posibilidad de imaginar otros devenires que hoy aparecen como truncados. El autor apelará a ella bajo la noción de nostalgia reflexiva: no una melancolía pasiva sino un gesto crítico, que pone en tela de juicio las configuraciones del presente.

El caso que examinamos en este artículo profundiza, desde sus especificidades locales, el sentido de esta nostalgia del futuro, desplegando una forma de nostalgia reflexiva activada por la mirada crítica. La Villa Ministro Carlos Cortés no nos remite simplemente a edificaciones en deterioro, sino más bien a los cimientos de un proyecto que nunca desplegó toda su potencia. En línea, nuevamente, con lo que ha planteado Beasley Murray a propósito del Hospital Ochagavía (2015), observamos que la Villa -en tanto hito urbano icónico del programa de la Unidad Popular- "se presenta como un reproche silencioso, como un recordatorio insistente de lo que pudo haber sido" (Beasley Murray, 2015, s/p). De este modo, se trata de unas ruinas en las que no se añora una materialidad derruida y sus usos 
extintos, sino la ilusión interrumpida de un proyecto de sociedad que fue apagado por la fuerza. Nos invita, entonces, a revisitar las bases conceptuales de la noción de ruina desde unas coordenadas políticas y culturales muy particulares.

Por una parte, la Villa San Luis -como también así Ochagavía- añade complejidad a los preceptos de la ruina moderna, y su correspondiente referencia al relato teleológico de la racionalidad. El concepto de ruina, tal y como aparece en la obra de Benjamin (2011) y de quienes lo sucedieron en estas reflexiones, se encuentra unido indisolublemente al paradigma moderno: al volver la vista al pasado, el Ángel de la Historia benjaminiano descubre los destrozos que ha dejado el progreso a su paso, y contempla atónito las ruinas de dicho vendaval (Márquez et al. 2019). La ruina, por tanto, constituye un espacio privilegiado para observar el curso del tiempo moderno, siempre proyectado hacia el futuro, así como también los efectos de su avance implacable. "En la continuidad de su disolución -afirma Trigg, en su "Estética de la decadencia”-, la ruina nos recompensa con una profunda perspectiva, y crea así un espacio en el que el fin de la racionalidad converge. Pensar junto a la ruina significa reconocer su capacidad de evaluar el progreso"8 (2006, p. xix). En este sentido, si las ruinas del primer mundo permiten observar el epílogo de la modernidad, cabe preguntarse por los modos en que se reordenan las lógicas y los tiempos en las ruinas de contextos culturales que no pueden explicarse del todo desde dicha narrativa lineal. ¿Qué convergencias tienen lugar en las ruinas donde la modernidad no fue sino un sitio en obras, donde la historia se ha escrito más bien en líneas espirales, y donde los discursos de la razón convivieron siempre con otros registros? La experiencia de la Villa San Luis puede entregarnos una perspectiva sugerente, pues invita a observar el devenir de otros modos de flujo temporal, que no responden directamente a un vector lineal y progresista; y de otros códigos lógicos, en los que la norma escrita es desoída desde los poderes fácticos y la racionalidad puede explicar apenas una fracción de los acontecimientos. Nuevamente en la clave de lo apuntado por Beasley Murray para Ochagavía, esta utopía inconclusa es, en esta coyuntura marcada por los desencuentros simbólicos y las batallas legales, "una estructura que se niega obstinadamente a que la sobrepasen o sobrescriban”, y que "parece resistir cualquier tentativa de finalización, de articular su significado dentro de un proyecto hegemónico” (2015, s/p).

Como hemos esbozado anteriormente, sostenemos que las ruinas de la Villa San Luis operan como un bache estético que hace tambalear la pretendida continuidad de la ciudad contemporánea, y sus consabidos discursos enfocados en el progreso capitalista. En tanto quiebre sensorial -visible, audible y experimentable- del entorno donde se emplaza, el sitio semiabandonado que es hoy este proyecto pone en crisis a la ciudad hegemónica en al menos tres niveles: (a) en tanto desafía a la ciudad segregada que expulsa a los pobres a las periferias; (b) en tanto se rebela frente a la ciudad sin memoria; y (c) en tanto se resiste a los "procesos capitalistas de acumulación y devastación" (Villalobos-Ruminott, 2017) que caracterizan el paisaje urbano contemporáneo. Examinaremos brevemente estas tres dimensiones.

$8 \quad$ La traducción es nuestra. 
En primer lugar, la persistencia durante todos estos años de los vestigios de la Villa San Luis en una zona estratégica de una de las comunas más caras de Chile, opera a contracorriente de los procesos de construcción de la ciudad de Santiago de las últimas décadas, que se han caracterizado por una creciente segregación social. Esta ciudad segmentada no es una articulación fortuita de los sujetos en la urbe, sino el producto deliberado de una política dictatorial de relocalizaciones: a fines de los años setenta, en el marco del régimen autoritario de A. Pinochet, los sectores urbano-marginales deben someterse a las diversas fuerzas neoliberales que los desplazan y transforman radicalmente su lugar en la ciudad. El desplazamiento masivo de los pobladores durante aquellos años, producto del proceso de erradicación de campamentos, de la política de reforma comunal y de la Política Nacional de Desarrollo Urbano, "ha configurado -desde un punto de vista socioespacial- la concentración de la pobreza urbana en áreas previamente escogidas, preferentemente en entornos periféricos, desarticuladas del resto de la ciudad y, por ende, de la sociedad" (Morales \& Rojas, 1986, p. 137). Aun cuando esta condición segregada es inherente a la ciudad desde su propia fundación, es durante la dictadura (1973-1989) que se disuelven los instrumentos de planificación urbana y "que la ciudad es desgajada y mutilada de aquellos fragmentos que la hacían más urbana, más diversa y heterogénea” (Márquez, 2017, p. 232). Se consolida, de este modo, la brecha entre las comunas ricas y las comunas pobres, con todas las consecuencias sociopolíticas que dicha distribución por clases acarrea. Es así como la Villa San Luis, en tanto proyecto revolucionario que integraba a los sectores vulnerables en el corazón del sector oriente santiaguino, cuestiona la desigualdad en el valor del suelo urbano y desoye las leyes del mercado: su supervivencia ruinosa se nos presenta como un terco remanente de la utopía socialista que antecedió a las políticas dictatoriales de la segregación, rebelándose a éstas desde el propio corazón de Las Condes.

En segundo lugar, las ruinas de la Villa nos sitúan frente a la necesidad de la memoria política. En este caso, no estamos solamente ante el efecto de las presiones neoliberales sobre el suelo del sector oriente de Santiago: se trató de un desplazamiento forzoso, que puso fin a la residencia de los pobladores en estos terrenos por medio de una violencia indiscutible. Durante esas noches de 1976, las familias que habitaban el complejo habitacional recibieron una carta, lanzada por debajo de sus puertas, donde se notificaba el término de su "ocupación ilegal" y la consecuente reubicación en nuevas dependencias. Se exigió por altoparlantes el abandono inmediato de los departamentos por parte de los moradores, despertando a niños y ancianos y montándolos en camiones hacia destinos inciertos. "20 familias quedaron en una cancha de fútbol en el paradero 37 de Santa Rosa, ocho en medio del camino a San José de Maipo, cuatro en un basural en las inmediaciones de Lo Curro y unas ochenta en Renca", afirma el revista Ercilla del 10 de enero de 1977 (Lawner, 2007). De este modo, tal y como queda expresado en la declaratoria de este sitio como Monumento Histórico Nacional (2017), los restos de la Villa San Luis permiten recordar a la sociedad que en dicho lugar la dictadura llevó a cabo un desalojo forzado de los pobladores, despojando violentamente a sus legítimos 
moradores de sus viviendas. Es por ello que, en el marco de la política reparatoria del Estado, el debate en torno al destino final de estos terrenos gira en torno a la construcción de un sitio de memoria, ya sea en forma de monumento, museo u otra modalidad de arte público.

Hay un tercer nivel en el que estas ruinas significan un quiebre con el relato oficial de la ciudad: así como supone la irrupción de un sujeto social "otro” en el territorio de las élites, e introduce la memoria de un pasado histórico que ha quedado invisibilizado, las materialidades que restan de la Villa San Luis dan cuenta también de un estilo de vida que el capitalismo voraz parece estar aniquilando. Frente a la escala humana de unas edificaciones que promovían la trama vecinal y la vida de barrio, el entorno de la Villa San Luis ha sido absorbido por enormes edificios corporativos que imponen sus ritmos y sus flujos acelerados. Las fotografías de los últimos habitantes del conjunto en su vida cotidiana nos devuelven imágenes que contrastan con la imponencia de las torres: unas cuantas gallinas domésticas deambulando por los patios comunes; adornos navideños y dieciocheros colgando de marcos y ventanas; una terraza exterior con cajas y sillones; un jardín de maceteros en la caja de escalera (Contreras, 2014). Esta estética popular, que hace manifiesto el uso y la ocupación diaria del espacio, pone en escena un tipo de habitar que no resulta admisible para el proyecto imperante en la ciudad contemporánea. En tiempos en que la vivienda es un bien de inversión especulativa, el derecho a la ciudad parece vaciarse de sentido y resignarse a su ejercicio ocasional. Proliferan, en cambio, los tablones de aglomerado que cubren las manzanas de una ciudad en obra permanente: esta “arquitectura involuntaria de la destrucción” -en términos de Villalobos-Ruminott- subraya el hecho de que la segregación exponencial es subsidiaria del hambre capitalista. Se produce, así, una "intensificación de la devastación en nombre de un habitar cuya promesa se sostiene sobre la puesta en riesgo del mismo habitar" (VillalobosRuminott, 2017, p. 16).

No es casualidad que uno de los actores centrales en las disputas recientes en torno a la Villa San Luis sea una inmobiliaria, y que a lo largo del proceso judicial su capacidad para imponer una agenda -incluso a través de resquicios y triquiñuelas- resulte aplastadora frente a las agencias ciudadanas que se han movilizado para proteger el espacio. Como sugiere A. Stoler, la noción de ruina debe entenderse tanto en términos de un estado de las cosas (un sustantivo) como en términos de un proceso que las afecta (un verbo); y ese proceso no solamente es el efecto del deterioro natural que ocurre con el paso del tiempo. La "ruinación” es también "un proyecto político que deja residuos en ciertas personas y lugares, relaciones y cosas" (Stoler, 2008, p. 196), y que debe concebirse como la intervención activa de diversos entramados de poder. El destino contemporáneo de la Villa se encuentra marcado por la acción deliberada de ruinación por parte de agentes públicos y privados, desde las presiones y hostigamientos -primero de los militares, luego de las inmobiliarias- efectuados para expulsar a los habitantes; hasta el inicio de su demolición parcial que encuentra un momento icónico en 1997, cuando el propio edil de la comuna de Las Condes -un Joaquín Lavín de casco y retroexcavadora- inaugura la destrucción del inmueble en un televisado espectáculo 
(Lawner, 2007). No obstante, frente a la ruinación implacable de la Villa San Luis se ejercen resistencias múltiples: las de los pobladores que a pesar del acoso se negaron por largos años a abandonar sus departamentos (Toro, 2014); y las de la propia materialidad del inmueble, cuya solidez ejemplar dificultó seriamente las faenas de demolición, contrastando con el estrepitoso anegamiento -en esos mismos días de 1997-, de las viviendas sociales Copeva.

\section{FORMAS PROVISORIAS DE CONJURAR EL PASADO}

Este artículo plantea que, en su capacidad de suspender la continuidad del tiempo/ espacio urbano, la ruina introduce un quiebre sensorial que pone en crisis el relato hegemónico de la ciudad contemporánea. Su diferencia, sin embargo, no siempre es percibida y significada por quienes la circundan de forma cotidiana: a menudo la ruina se encuentra oculta a plena vista en medio del ritmo acelerado de la urbe. Examinaremos a continuación una serie de intervenciones u obras artísticas recientes que trabajan en torno a la Villa San Luis, desplegando estrategias visuales diversas para devolver visibilidad y legibilidad a sus residuos materiales. Como la propia idea de ruina, estas propuestas plásticas y performáticas operan en un territorio abierto a significaciones múltiples, marcadas por la indeterminación y la potencia de aquello que se sugiere y se connota. Lejos de amarrar un relato unívoco, estas producciones artísticas exploran desde una dimensión sensible el poder evocativo de la ruina, restituyendo por medio de recursos estéticos el valor singular de un espacio amenazado por el avance de la urbe.

En cierta medida, las ruinas y las artes pueden ser comprendidas como categorías análogas, puesto que ambas trabajan alrededor de lo que N. García Canclini ha llamado la "inminencia". Para el autor, parte del atractivo del arte radica en que "anuncia algo que puede suceder, promete el sentido o lo modifica con insinuaciones" (2011, p. 12). Desde sus herramientas enraizadas en lo sensible, las artes escapan de los hechos duros y de las producciones ocluidas: necesariamente dejan espacio a la interpretación y la duda; a la experiencia subjetiva de sus espectadores; a las ambigüedades que connotan desde la indeterminación. Citando a Borges, García Canclini nos habla de la "inminencia de una revelación" que insinúa sin llegar a nombrar. Inminencia que, sin embargo, no acaba de producirse. En razón de lo que hemos sostenido en líneas anteriores, también la ruina se mueve en este registro incierto, donde los pedazos rotos dejan entrever los destellos de un pasado que no termina nunca de completarse. "Las obras no simplemente 'suspenden' la realidad -agrega García Canclini, en una descripción que bien podría aludir a las ruinas, y sobre todo a las de la Villa San Luis-; se sitúan en un momento previo, cuando lo real es posible, cuando todavía no se malogró. Tratan los hechos como acontecimientos que están a punto de ser" (2011, p. 12). Si continuamos en la senda del autor, podemos incluso establecer cierta correspondencia entre el par de conceptos «ruina» e «inminencia» con otro binomio que opera como contrapunto: «patrimonio» y «exminencia». "Los profesionales del 
patrimonio se ocupan de lo que llamaremos la exminencia" -dice el citado autor-. Si el arte y la ruina se sitúan en el ámbito de lo inasible, el dominio del patrimonio cobra la forma de una apropiación; de un ejercicio de montaje y edición de los sentidos que portan los objetos, los cuales "congelan la proyección virtual de las tentativas y las reducen a obras" (2011, p. 111).

Los vestigios de la Villa San Luis permiten observar con claridad el parentesco entre arte y ruinas, en tanto su materialidad derruida hace posible reconstituir en la imaginación aquel espacio clave para el proyecto socialista antes de que fuera lapidariamente silenciado. A través de sus diversos soportes y formatos, las propuestas artísticas contemporáneas que han abordado el caso de la Villa San Luis operan, entonces, sobre esta doble condición contingente: en tanto la propia ruina es un territorio abierto a narrativas fragmentarias y múltiples, y en tanto los medios artísticos utilizados exploran lo sensible como un proceder que sugiere sin certezas. En la última década, es posible identificar alrededor de una decena de proyectos artísticos de diferente naturaleza que giran en torno a la Villa San Luis; muchos de los cuales han intentado construir condiciones de visibilidad para esta historia inconclusa. En 2008, en el marco de su tesis de Magíster en Artes Visuales, Lucrecia Conget realizó dos intervenciones en los blocks deshabitados que apuntaban a iluminar -real y metafóricamenteestas estructuras en abandono, como un modo de devolver relevancia a un conjunto de edificios que se "encuentra sumido en las sombras en comparación a los imponentes y luminosos edificios que, de a poco, la están desplazando" (Conget, 2010, p. 60). Así, tras ingresar clandestinamente una noche, la artista instaló una luz de emergencia en lo más alto del block, la cual tras un par de horas había desaparecido: ello le sirvió de evidencia de que, aun tratándose de un inmueble abandonado, tenían lugar allí diversas prácticas que daban cuenta de éste como un espacio vivo (Fig. 1). También apela a la estrategia de la iluminación la instalación de Valentina Henríquez, titulada precisamente "Villa San Luis" (2013, Galería Macchina): a partir de un registro fotográfico de las materialidades remanentes de este proyecto emblemático de la Unidad Popular, la artista elabora un conjunto de cajas de luz construidas en base a cajones de tomates; proporciona, de este modo, un nuevo marco para restituir la atención a este espacio desapercibido en el medio de la ciudad vertiginosa (Fig. 2).

Por su parte, los trabajos -aún en construcción- de Tamara Contreras utilizan la expresión abstracta para problematizar la visibilidad y la legibilidad de la Villa San Luis. La artista, activamente involucrada en la Fundación de defensa de la Villa, inició sus indagaciones en torno a este sitio mientras cursaba la carrera de artes visuales, generando un significativo archivo fotográfico que documenta minuciosamente los últimos años de ocupación de los inmuebles por parte de los pobladores, ofreciendo un lugar privilegiado al registro de la vida cotidiana de sus habitantes. Parte de estas fotografías fueron expuestas en el Museo de la Memoria y en la exposición "El derrumbe de un sueño" (2018, Espacio O), y pronto serán publicadas en formato de libro. Formada inicialmente en la pintura abstracta, Tamara ha encontrado un modo de proyectar estas inquietudes en torno a la Villa desde dicho lenguaje visual: una vibrante paleta de colores recrea estas icónicas fotografías del sitio, ofreciendo 


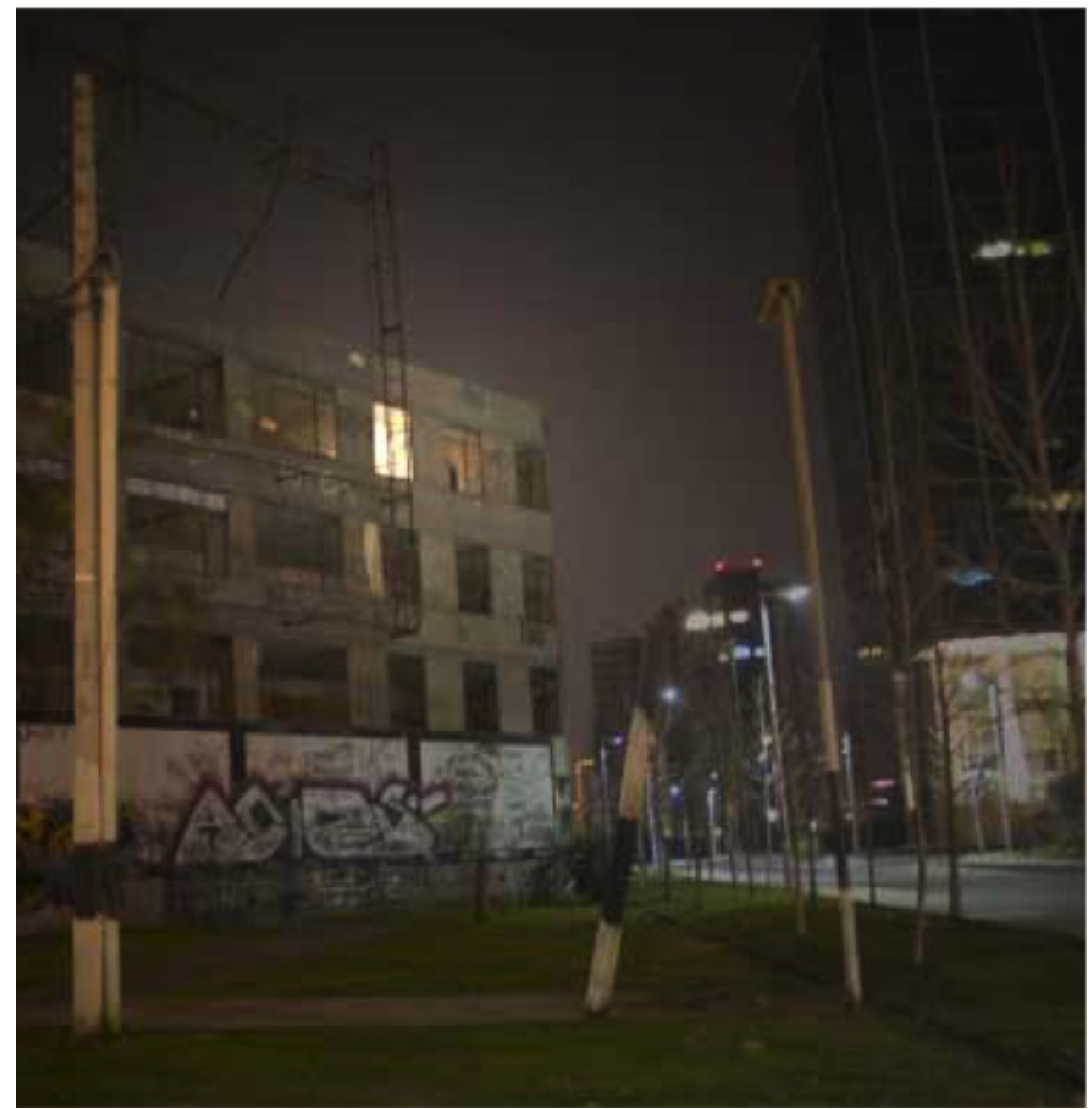

Fig. 1. Intervención en Villa San Luis de Lucrecia Conget (2008). Fotografía: Claudia Lee.

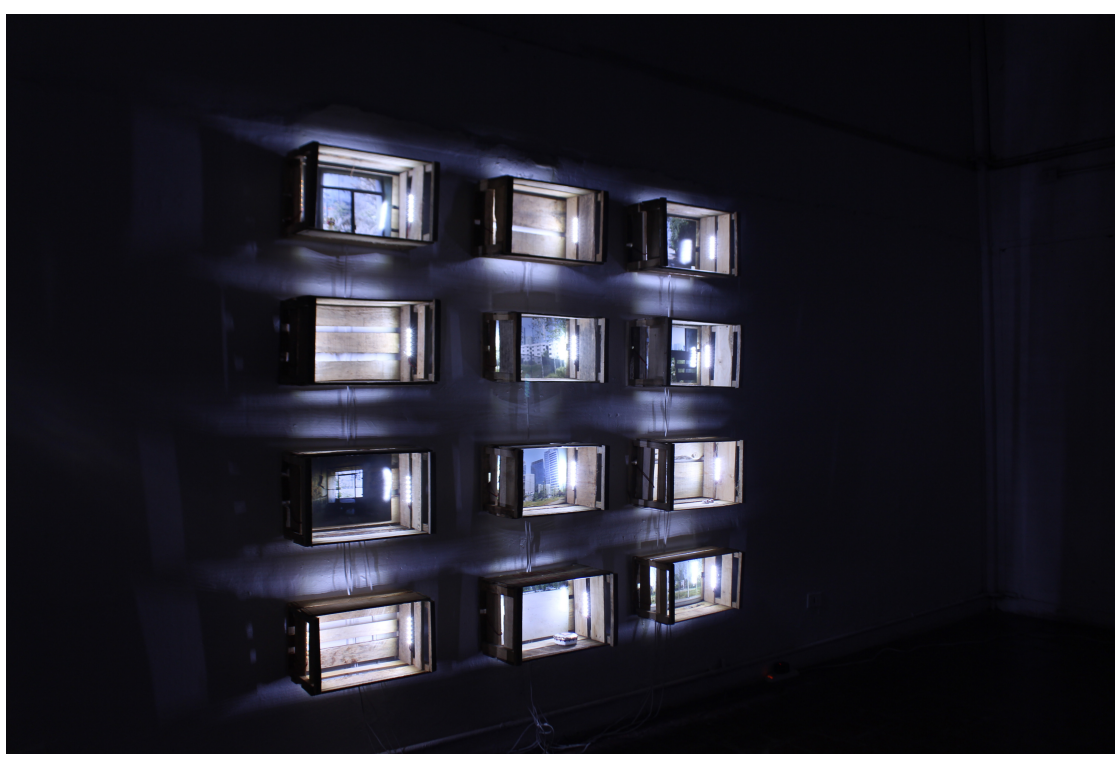

Fig. 2. Villa San Luis de Valentina Henríquez (2013). Fotografía: Valentina Henríquez. 
nuevos ángulos de mirada para una estructura que, como un destino inevitable, nos remite al desplome de los emblemáticos blocks (Figs. 3, 4, 5 y 6).

La producción artística en torno a este sitio, en el marco de la ya mencionada doble contingencia, ofrece una entrada singular a los modos en que la ruina rompe con la continuidad espacio-temporal de la ciudad pretendida. Nos detendremos brevemente en algunas iniciativas de artistas que dan cuenta de este quiebre en las tres dimensiones

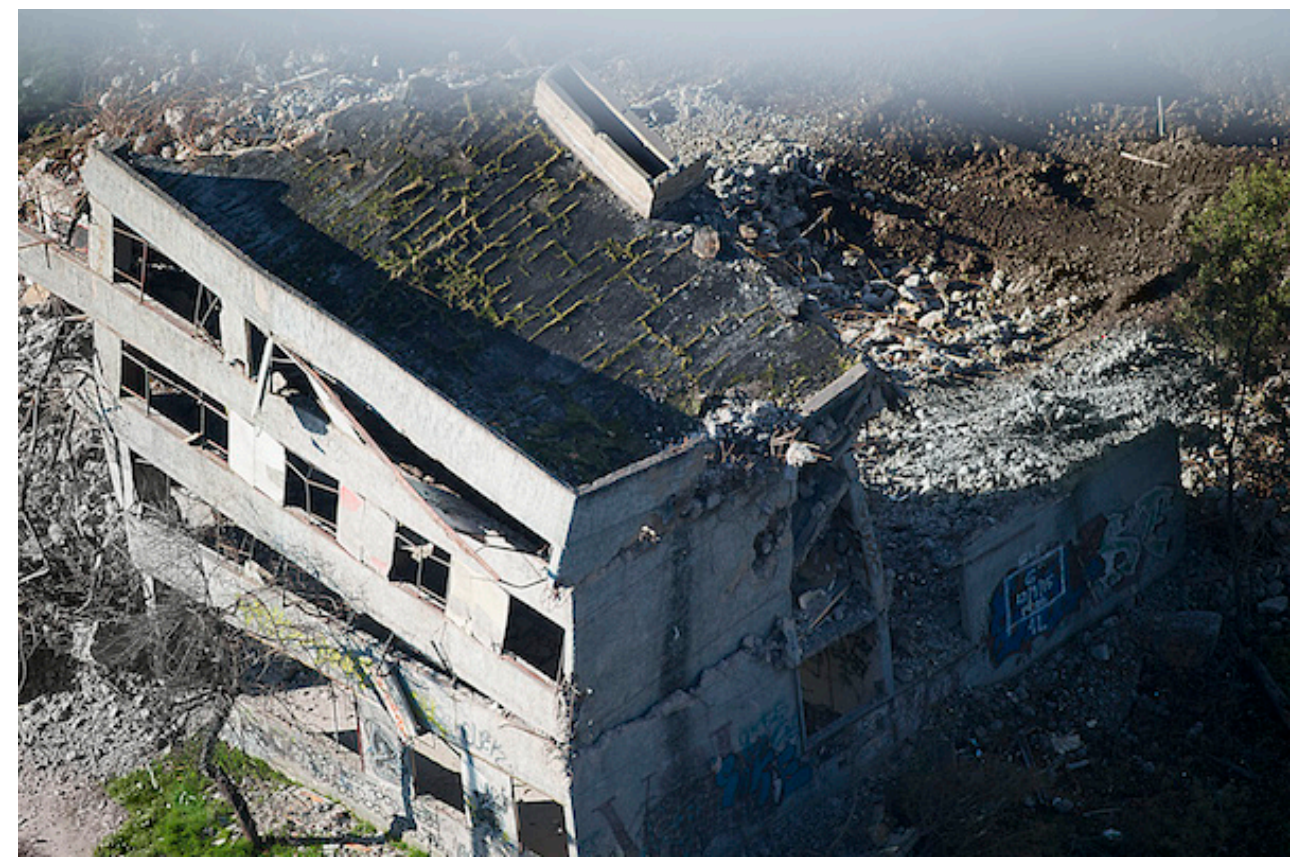

Fig. 3. Villa San Luis. Fotografía: Tamara Contreras Landeros.

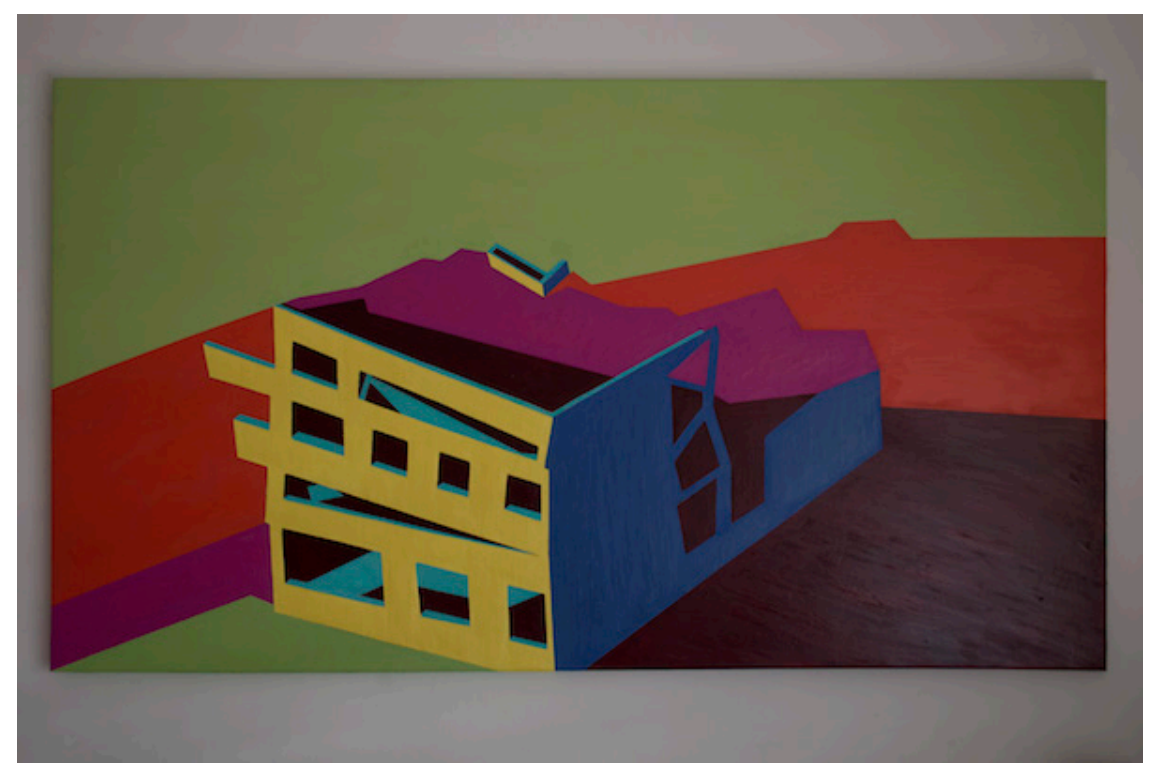

Fig. 4. Obra en proceso de Tamara Contreras Landeros. 


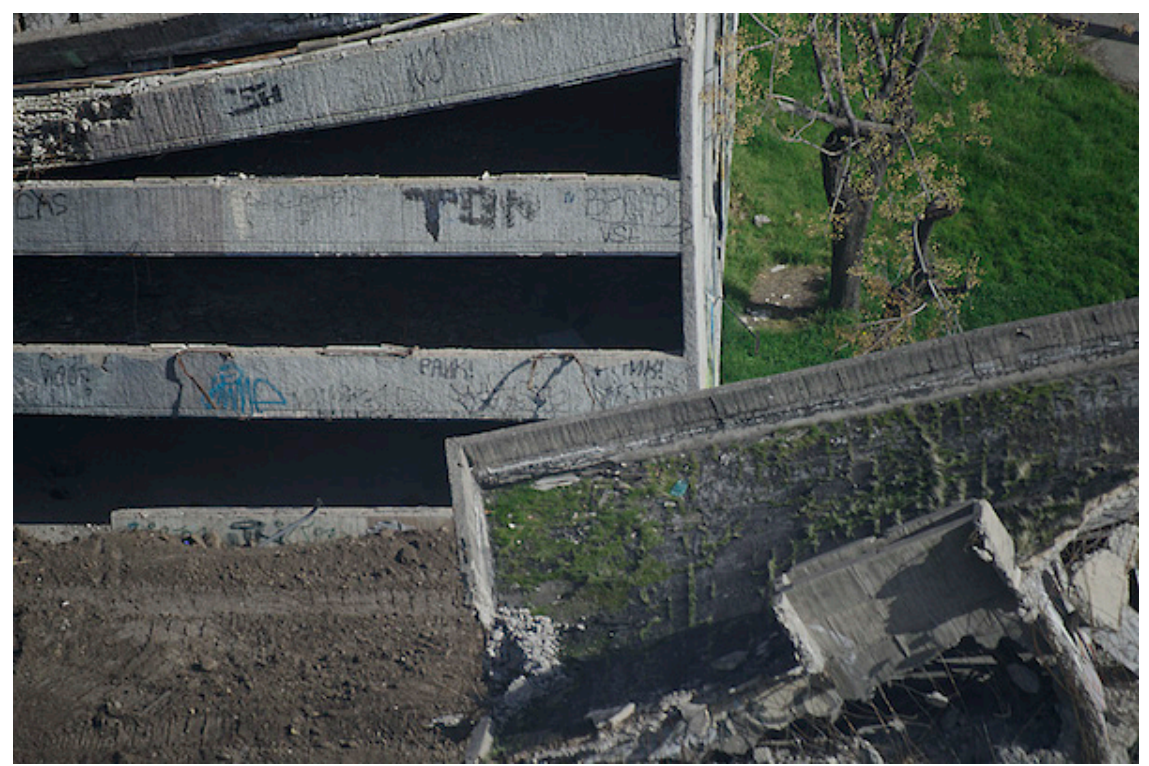

Fig. 5. Villa San Luis. Fotografía: Tamara Contreras Landeros.

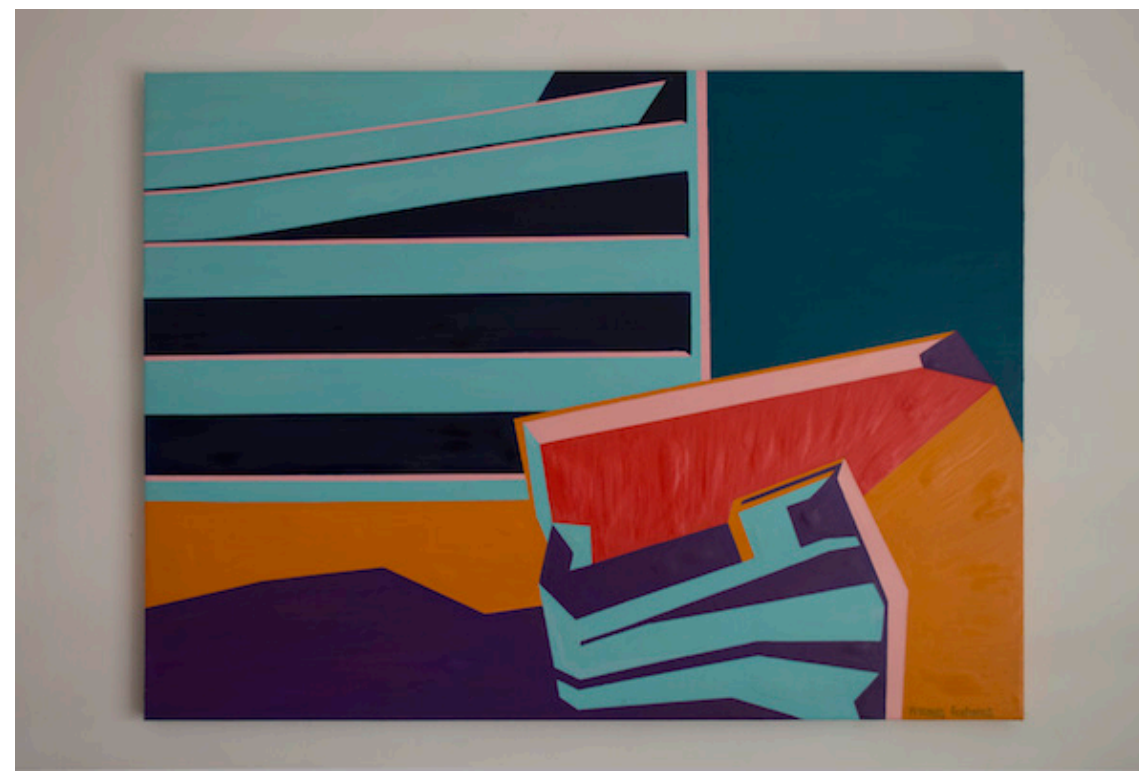

Fig. 6. Obra en proceso de Tamara Contreras Landeros.

mencionadas en el apartado anterior, que sintetizaremos aquí como la ciudad segregada, la ciudad sin memoria y la ciudad deshabitada de la especulación capitalista. Sostenemos que las aproximaciones desde las artes visuales constituyen modos sugerentes de elaborar un relato a partir de los retazos materiales disponibles en el sitio, a través de imágenes y gestos que devuelven la atención a aquello que puede pasar desapercibido. Lejos de la vocación definitiva de los monumentos, memoriales y sitios de memoria, estas propuestas artísticas suelen consistir en intervenciones efímeras que trabajan, precisamente, en los intersticios. 
Como la propia ruina, y a diferencia de la lógica patrimonial con sus inscripciones perennes, se trata de estrategias que habitan un mientras: son formas provisorias de conjurar un pasado que amenaza con disolverse.

(1) La ciudad segregada. En 2014, Manuela Flores recibió una invitación a participar de una exposición colectiva en el Parque Araucano, convocada por YAP- MoMA (Young Architects Program del MoMA PS1). Se le asignó, por tanto, uno de los veintitantos módulos que disponía el pabellón transitorio: aprovechando su emplazamiento estratégico, la artista instaló una escalera roja que iba más allá del techo y permitía reencontrarse con el lugar desdibujado por los monótonos módulos. Herramienta básica para cualquier construcción -dice la artista-, esta escalera de cinco metros de altura ofrecía una vista panorámica al centro empresarial que rodea el Parque Araucano, distinguiéndose al fondo los restos abandonados de los blocks de la Villa San Luis ${ }^{9}$ (Figs. 7 y 8). Los peldaños rotulados con años significativos de esta historia de utopía y despojo se presentan ante el espectador en un orden saltado e ilegible, como los propios escombros de los edificios se acumulan en estratos desorganizados y densos. De este modo, a través de un gesto sencillo, la artista ofrece una suerte de prótesis para la mirada, que permite poner en crisis el relato en torno al paisaje urbano que ha prevalecido en el presente: tras las operaciones inmobiliarias y empresariales que configuran la ciudad contemporánea, quedan los resabios de un proyecto social que buscaba integrar a los sujetos a sus dinámicas nucleares, y que incluso soñó con incorporar el Parque Araucano a este centro cívico del proyecto socialista.

(2) La ciudad sin memoria. Aunque el colectivo Ejercicios Impermanentes ha concentrado sus intervenciones en los sitios eriazos de la ciudad de Valparaíso -donde residen sus creadoras, las artistas Elisa Assler,

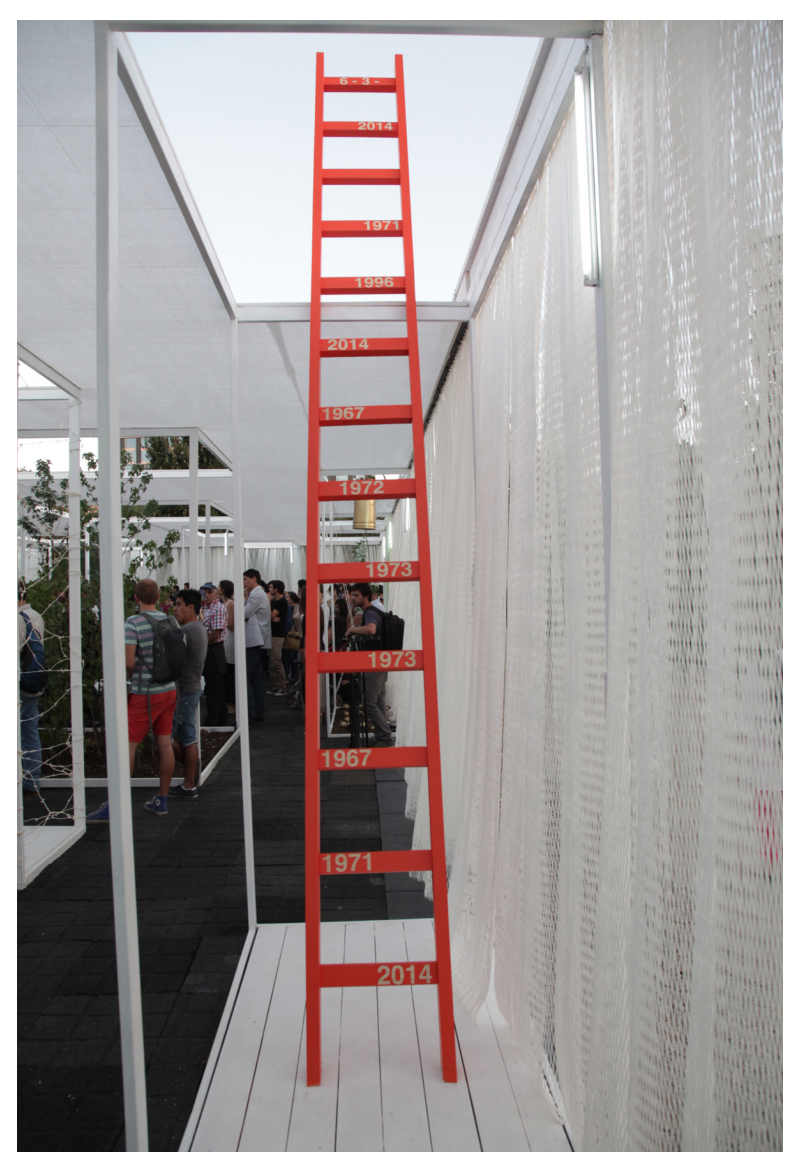

Fig. 7. "Escala” de Manuela Flores (2014).

9 http://escuelaarte.uc.cl/index.php/alumnos-y-exalumnos/polyhedron/artistas-polyhedron/183-manuela-flores 


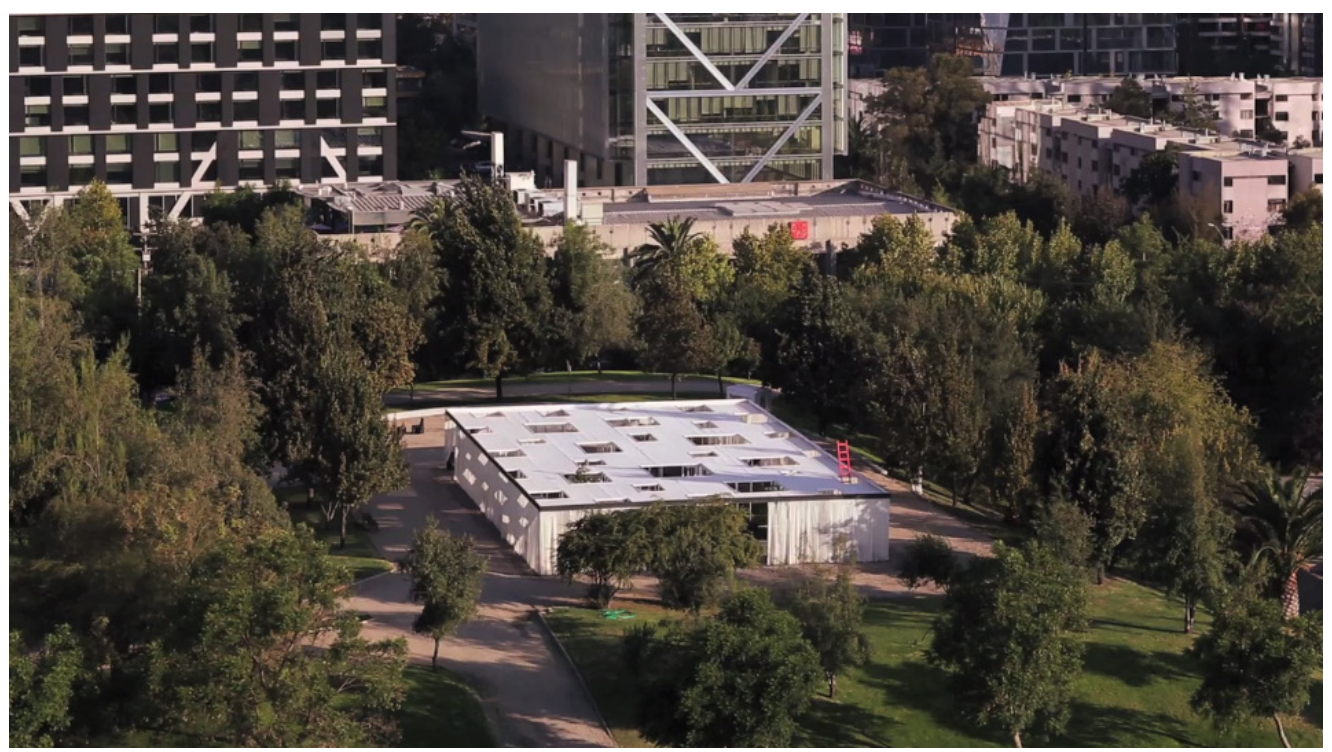

Fig. 8. "Escala” de Manuela Flores (2014).

Anamaría Briede y la arquitecta Manuela Tromben-, la oportunidad de exhibir su trabajo en la Sala de Arte de Las Condes sirvió de gatillo para la realización de una experiencia en la ciudad de Santiago. Mientras trabajó como arquitecta en la construcción del edificio de CorpArtes, Manuela observaba los contrastes de los edificios corporativos y este sitio derruido que correspondía a las ruinas de la Villa San Luis. Se trataba de un espacio invisible, a pesar de estar en el centro de este álgido punto urbano: nadie se daba cuenta de que estaba ahí. Esta curiosidad fue el punto de partida de una investigación que les reveló la historia del proyecto de viviendas sociales cuyos dueños fueron desalojados por la dictadura militar. La performance "Cien Metros de Silencio" (2017) apela a los recursos del ritual para intervenir el espacio de la ruina, llevando a cabo un homenaje a aquellas familias que fueron despojadas de sus viviendas: desenrollando cien metros de tela blanca de 1,4 m de ancho alrededor del lote 18 de la Villa, el colectivo ensaya un modo peculiar de subrayar este territorio desapercibido, a partir de la materialidad de la tela y las posibilidades plásticas de sus propios cuerpos (Figs. 9 y 10). De este modo, merodeando el sentido y la propia ruina (a la que nunca ingresaron), las artistas exploran las posibilidades del lenguaje poético para romper con el olvido de esta historia truncada. El registro audiovisual, cuyas cuidadas tomas en blanco y negro remarcan el contraste entre la materialidad de la ruina y la presencia excepcional de la tela que la enmarca, está lleno de imágenes sugerentes: los modos en que la línea blanca se proyecta en los edificios espejados; el aparecer y desaparecer de los cuerpos con la Villa como telón de fondo; y finalmente, el desenlace fatídico de un paisaje de derrumbe: retroexcavadoras, escombros, estructuras que ceden. Alejándose de los recursos panfletarios y explícitos, Ejercicios Impermanentes realiza este homenaje valiéndose del silencio y de los contrastes, dando lugar a una acción 
efímera que sin embargo logró estar en el momento y lugar indicado: una semana después de esta intervención artística, tal y como observamos en el epílogo del video de registro, se inicia la demolición parcial de la Villa y se da curso a la declaratoria patrimonial del sitio como Monumento Histórico.

(3) La ciudad deshabitada. Al observar el registro de la intervención artística de Valentina Utz en la Villa San Luis (2009), nos encontramos con un paisaje urbano que hoy -casi diez años después- ha desaparecido. Los extintos blocks de este proyecto de vivienda social se encuentran, por aquel entonces, atiborrados de desechos de diversa

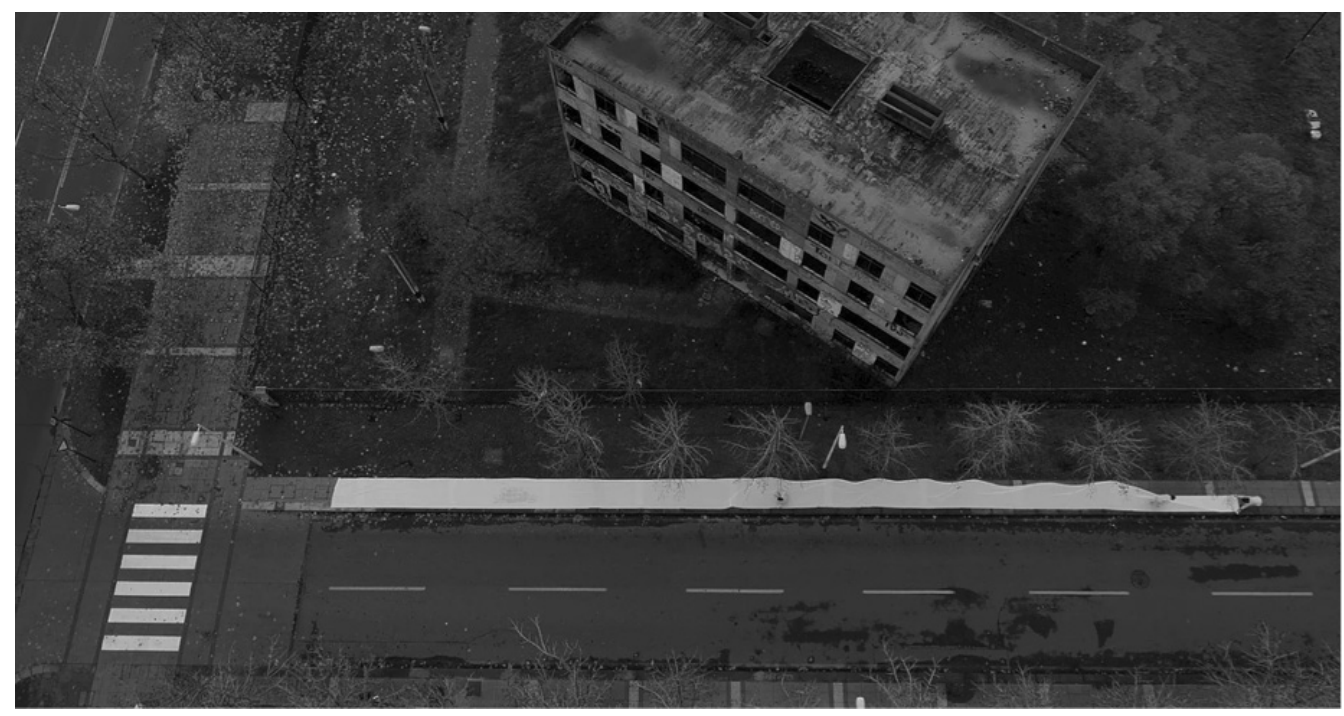

Fig. 9. “Cien metros de silencio” de Colectivo Ejercicios Impermanentes (2017).

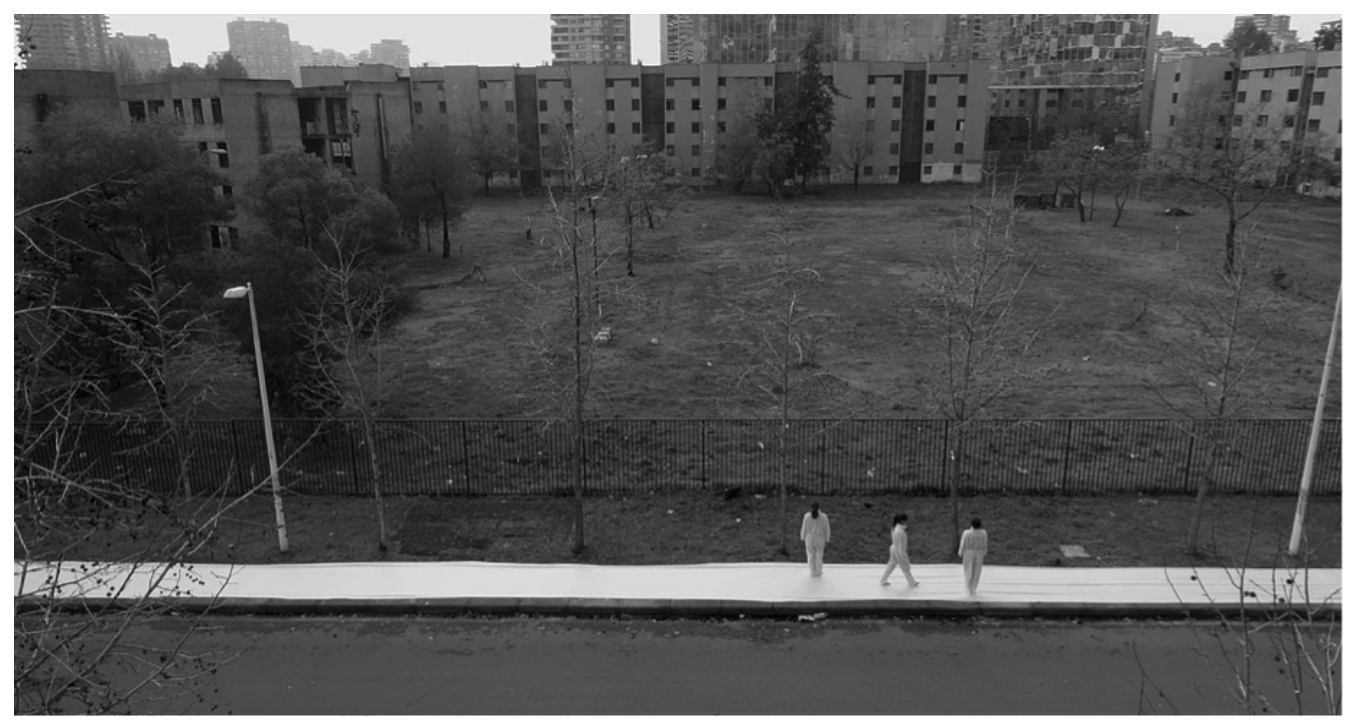

Fig. 10. "Cien metros de silencio" de Colectivo Ejercicios Impermanentes (2017). 
índole, dando cuenta de la vigencia de ciertas prácticas de ocupación del espacio que con el tiempo se volvieron cada vez más inaccesibles. La artista convierte esta basura en el insumo principal de su performance: utilizando los marcos desnudos de las ventanas del block como vitrina, Utz dispone conjuntos de objetos desechados de modo que resulten visibles desde la distancia. Cada marco aloja, de esta forma, un tipo particular de desperdicio, agrupado por criterios formales o funcionales: una serie de botellas plásticas ordenadas por color, unos retazos de cajas de cartón, una colección de bolsas de basura, fragmentos de plástico naranjo (Fig. 11). Estas operaciones intentan llamar la atención acerca de lo que la artista nombra como "el cambio de barrio": en uno de los suelos más costosos de la ciudad, apropiado por la dinámica de las grandes empresas, hubo un proyecto de vivienda que resiste convertido en vertedero ilegal ${ }^{10}$. Así, en esta acción observable desde la vía pública, los recursos sensibles del arte permiten poner en escena otros usos posibles de un terreno que ha sido apoderado por el mercado inmobiliario: formas de un habitar popular que hoy se encuentra relegado a la noche, la sombra y la clandestinidad.

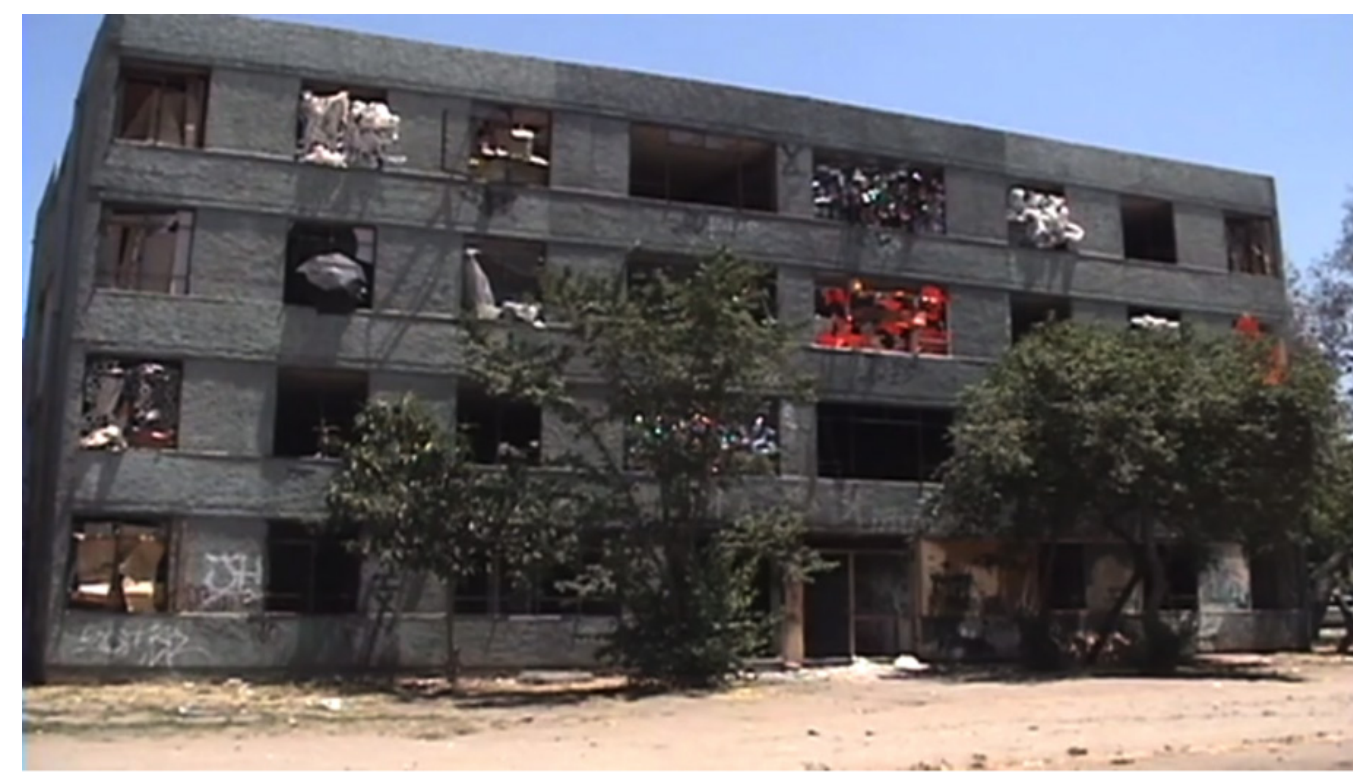

Fig. 11. Fotograma de "Villa San Luis" de Valentina Utz en colaboración con Matías Klenner (2009). Registro: Matías Klenner.

\section{CONCLUSIONES}

Hemos observado, a partir de una serie de obras artísticas que toman las ruinas de la Villa San Luis como objeto de indagación, cómo se despliegan en la ciudad diversas interrupciones sensibles que ponen en suspenso la continuidad de la ciudad hegemónica.

10 https://vimeo.com/78417211 
Las artes y las ruinas operan a través de la inminencia: lejos de tranquilizarnos con certezas, se mueven en el plano de lo indeterminado y de lo ambiguo; de aquello que se convoca pero no se nombra de forma explícita. Como ha apuntado Trigg (2006), las ruinas (y, podríamos agregar, el arte) no pertenecen a nadie: multiplican las temporalidades, dislocan las categorías sensoriales; subrayan la discontinuidad y la no linealidad del tiempo. Es por ello que podemos entenderlos, siguiendo a M. Foucault, como la expresión de una "heterotopía” (1999).

Las ruinas de la Villa San Luis, suspendidas en el medio de intensas disputas sociales, políticas y judiciales, conforman un escenario en el que convergen y colisionan diversos proyectos de ciudad. Su condición de ruina, en tanto categoría intermedia que une de forma inestable materialidad y relato, nos permite reflexionar acerca de los modos en que las utopías políticas del pasado coexisten con las narrativas modernizantes de la actualidad, y las formas en que otras memorias y otros modos de habitar subsisten en la trama urbana contemporánea. En este texto, quisimos entregar algunas luces acerca de la productividad de aquella doble contingencia del arte sobre la ruina; aunque nuestras claves de lectura no pueden sino ser también contingentes, esperamos que estas reflexiones puedan abrir nuevas aristas del problema, que pongan la dimensión sensible en el centro del análisis.

\section{REFERENCIAS}

Allende, F., \& Olave, S. (2018). El despojo de la Villa San Luis de Las Condes. Santiago de Chile: Ceibo Ediciones.

Beasley Murray, J. (agosto de 2015). La utopía en ruinas: el hospital Ochagavía. En Actores, demandas e intersecciones. Trabajo presentado en el I Simposio de la Sección de Estudios del Cono Sur (LASA), Santiago, Chile.

Benjamin, W. (2011). Libro de los Pasajes. Madrid: Akal.

Cerna, T. (24 de julio de 2018). Suprema rechaza recurso y declara la Villa San Luis de Las Condes como monumento histórico. Emol. Recuperado de https://www.emol.com/ noticias/Nacional/2018/07/24/914451/Suprema-declara-la-Villa-San-Luis-en-LasCondes-como-monumento-historico.html

Chiara, M., \& Pulgar, C. (2008). Villa San Luis de Las Condes: Lugar de memoria y olvido. Revista de Arquitectura, 18, 28-40.

Conget, L. (2010). Parpadeos. Estrategias de actualización y resignificación de archivo. Tesis para optar al grado de Magíster en Artes, mención Artes Visuales. Universidad de Chile. Consejo de Monumentos Nacionales (2017). Acta sesión ordinaria del Consejo de Monumentos Nacionales, miércoles 28 de junio de 2017. Recuperado de http://www.monumentos.cl/ sites/default/files/20170628_ord_acta_env_def_0.pdf

Contreras, T. (2014). Villa San Luis. Las Condes. Santiago de Chile: Autoedición.

Déotte, J. L. (1998). Catástrofe y olvido. Las ruinas, Europa, el Museo. Santiago de Chile: Editorial Cuarto Propio. 
Foucault, M. (1999). Espacios Otros. Estudios de Comunicación y Política, 9, 15-26.

Gámez, V. (2006). El pensamiento urbanístico de la CORMU (1965-1976). Urbano, 9(13), 9-18. García Canclini, N. (2011). La sociedad sin relato. Antropología y estética de la inminencia. Buenos Aires: Katz Editores.

González, V. (29 de junio de 2017). Tras ser declarada Monumento Nacional, Las Condes frena demolición de Villa San Luis. El Mercurio, C-6.

Gross, P. (1991). Santiago de Chile (1925-1990): planificación urbana y modelos políticos. Revista de Estudios Urbano Regionales, 17(52/53), 27-52.

Huyssen, A. (2007). La nostalgia de las ruinas (Traductora Sarlo, B.). Punto de vista: Revista de Cultura, 87, 36-42.

Jelin, E., \& Langland, V. (2003). Las marcas territoriales como nexo entre pasado y presente. En E. Jelin \& V. Langland (Comps.), Monumentos, memoriales y marcas territoriales (pp. 1-18). Madrid: Siglo XXI.

Lawner, M. (2007). Demolición de la Villa San Luis de Las Condes: Historia de dos despojos. Copenhague: Centro de Estudios Nacionales de Desarrollo Alternativo.

Lawner, M. (2013). Expediente Santo Domingo: La demolición de un sueño. Recuperado de http://www.londres38.cl/1937/articles-95140_recurso_2.pdf

Lawner, M. (2017). Villa San Luis o la destrucción de la memoria. Demolida la obra de un Premio Nacional de Arquitectura. La voz de la Chimba, 41, 33-34.

Lazzara, M., \& Unruh, V. (2009). Telling Ruins. En M. Lazzara \& V. Unruh (Eds.), Telling Ruins in Latin America (pp. 1-9). Nueva York: Palgrave Macmillan.

Márquez, F. (2017). Relatos de una ciudad trizada. Santiago de Chile. Santiago: Ocho Libros Editores.

Márquez, F., Bustamante, J., Nuevo, A., \& Pinochet, C. (2019). Ruinas urbanas. Réplicas de memoria en la ciudad. MS.

Montealegre, P. (2010). Jardín para el pueblo. El imaginario de la Unidad Popular en el Parque O’Higgins . Tesis de maestría inédita. Instituto de Estudios Urbanos y Territoriales de la Pontificia Universidad Católica, Santiago, Chile.

Morales, E., \& Rojas, S. (1986). Relocalización socioespacial de la pobreza. Política estatal y presión popular, 1979-1985. Santiago: FLACSO, Documento de Trabajo.

Pavez, M. (2015). Cronología de la VI Exposición, Concurso Remodelación Santiago Centro 1972 y otros destacados 1965-1976. En M. Pavez. (Ed.), Diseño Urbano Inclusivo para Santiago Centro. Concurso Internacional 1972, Santiago de Chile (pp. 148-155). Santiago: Facultad de Arquitectura y Urbanismo de la Universidad de Chile.

Raposo, A., Raposo, G., \& Valencia, M. (2005). Hacia la remodelación democrática del espacio habitacional urbano. Un ensayo de interpretación crítica de la obra Arquitectónica y Urbanística de CORMU en Santiago, 1966-1976, Vol I. Diseño Urbano y Paisaje, 2(5), $1-26$.

Raposo, A., \& Valencia, M. (2009). Práctica política del diseño urbano. Notas sobre la vida 
institucional y labor de la Corporación de Mejoramiento Urbano, CORMU. 1966-76. Revista INVI, 19(49), 110-141.

Richard, N. (2009). Sites of Memory, Emptying Remembrance. En M. Lazzara \& V. Unruh (Eds.), Telling Ruins in Latin America (pp. 175-182). Nueva York: Palgrave Macmillan.

Sánchez, E. (2017). Entre la ciudad de la "participación popular” (1950-1973) y los “promotores inmobiliarios" (1978-2010). El caso Villa San Luis en Las Condes, Santiago de Chile. Revista CIS, 14(23), 57-76.

Schindel, E. (2009). Inscribir el pasado en el presente: memoria y espacio urbano. Política y cultura, 31, 65-87.

Siebert, F. (2015). El megaproyecto urbano que pretendía cambiar la calidad de vida del centro de Santiago a inicios de los 70's. Universidad de Chile. Recuperado de http://www. uchile.cl/noticias/116303/el-megaproyecto-urbano-que-pretendia-cambiar-el-centrode-santiago

Stoler, A. (2008). Imperial debris: Reflections on Ruins and Ruination, Cultural Anthropology, 23(2), 191-219.

Sugranyes, A. (2017). Villa San Luis. Primer paso para restablecer la justicia. La voz de la Chimba, 40, 2-3.

Raposo, A. (Ed.) (2001). Espacio urbano e ideología: El paradigma de la corporación de la vivienda en la arquitectura habitacional chilena. 1953-1976. Santiago: Universidad Central - Facultad de Arquitectura y Bellas Artes, Centro de Estudios de la Vivienda.

Toro, I. (19 de mayo de 2014). Villa San Luis: La caída del último bastión de Allende en Las Condes. The Clinic Recuperado de http://www.theclinic.cl/2014/05/19/villa-san-luisla-caida-del-ultimo-bastion-de-allende-en-las-condes/

Trigg, D. (2006). The Aesthetics of Decay: Nothingness, Nostalgia, and the Absence of Reason. Nueva York: Peter Lang.

Unidad Popular. (1970). Programa básico de gobierno de la Unidad Popular: candidatura presidencial de Salvador Allende. Santiago: Instituto Geográfico Militar.

Villalobos-Ruminott, S. (2017). Arquitectura y nihilismo. Notas sobre neoliberalismo y devastación. En A. Saavedra \& L. Alarcón (Eds.), Galería Metropolitana. 2011-2017 (pp. 16-19). Santiago: Galería Metropolitana. 